\title{
Changes in ruminal fermentation and microbial population of feedlot Nellore cattle fed crude glycerin and virginiamycin
}

\author{
Pablo S. Castagnino ${ }^{\mathrm{a}, *}$, Erick E. Dallantonia ${ }^{\mathrm{a}}$, Giovani Fiorentini ${ }^{\mathrm{a}}$, Elias San Vito ${ }^{\mathrm{a}}$, \\ Juliana D. Messana ${ }^{\mathrm{a}}$, Laís O. Lima ${ }^{\mathrm{a}}$, Tiago A. Simioni ${ }^{\mathrm{a}}$, Telma T. Berchielli ${ }^{\mathrm{a}, \mathrm{b}}$ \\ a Department of Animal Science, São Paulo State University (Unesp), School of Agricultural and Veterinarian Sciences, Jaboticabal, São Paulo, 14884 \\ 900, Brazil \\ ${ }^{\mathrm{b}}$ INCT/CA-UFV-Department of Animal Science, Av. Peter Henry Rolfs s/n, Campus Universitário, Viçosa, Minas Gerais, CEP 36570-000, Brazil
}

\section{A R T I C L E I N F O}

\section{Keywords:}

Beef cattle

Crude glycerin

Fermentation

Finishing diets

Virginiamycin

\begin{abstract}
A B S T R A C T
The objective of this experiment was to evaluate the effects of crude glycerin (CG) and virginiamycin (VM) diets on ruminal fermentation and microbial population of feedlot Nellore cattle. Eight rumen fistulated bulls (BW $=600 \pm 34 \mathrm{~kg} ; 26 \pm 3$ months) were used in a replicated $4 \times 4$ Latin square (21-d periods) with $2 \times 2$ factorial arrangement of treatments: diets without virginiamycin $(\mathrm{VM}-)$ or virginiamycin at $25 \mathrm{mg} / \mathrm{kg} \mathrm{DM}(\mathrm{VM}+)$ combined with diets without crude glycerin (CG - ) or CG (80\% glycerol) at $100 \mathrm{~g} / \mathrm{kg} \mathrm{DM}(\mathrm{CG}+)$. The sugar cane bagasse was used as the exclusive roughage in the proportion of $200 \mathrm{~g} / \mathrm{kg}$ in dry matter of diet and crude glycerin replaced corn in the diet formulation. Ruminal samples were collected immediately before feeding and at 3, 6, 12 and $18 \mathrm{~h}$ post feeding on days 20 and 21 of the sampling week. Data were analyzed in a replicated $4 \times 4$ Latin square with a $2 \times 2$ factorial using the MIXED procedure of SAS (SAS Inst., Inc., Cary, NC). There were no CG $\times$ VM interactions for any variable measured $(P \geq 0.10)$. The intake of DM had a tendency to be greater in CG + than CG - diets $(P=0.07)$. Apparent total tract digestibilities of nutrients were similar among diets $(P \geq 0.10)$. Diets with CG or VM had similar values of $\mathrm{pH}$ (mean $=6.15 ; P \geq 0.10$ ). Data showed that CG or VM did not affect the concentration of total VFA (116.92 mM; $P \geq 0.10$ ). The proportion of propionate increased $27.5 \%$ in $\mathrm{CG}+$ diets, regardless of VM inclusion $(P=0.01)$. Acetate:propionate ratio was lower in CG + compared to CG - diets (3.58 vs. 2.12; $P \geq 0.10)$. Valerate and butyrate proportion was greater in CG + than CG - diets $(P<0.05)$. The inclusion of VM or CG did not alter the relative abundance of fibrolityc bacteria $(P \geq 0.10)$. Total protozoa counts $(P=0.052)$ and Metadinium spp. $(P=0.058)$ had a tendency to decrease in VM + than VM - diets $(P<0.10)$. Crude glycerin had positive effects on rumen fermentation products and can replace virginiamycin with increment of Megasphaera elsdenii abundance. However, combining virginiamycin and glycerin does not affect positively rumen fermentation and growth of bacteria that metabolize lactate.
\end{abstract}

\section{Introduction}

Feedlots diets of beef cattle are generally rich in grains with high starch content. The great concentration of starch present in

\footnotetext{
Abbreviations: aNDFom, NDF without sodium sulfite, with alpha amylase and corrected for residual ash; CG, crude glycerin; CP, crude protein; DM, dry matter; DMI, dry matter intake; EE, ether extract; BW, body weight; OM, organic matter; VFA, volatile fatty acids; VM, virginiamycin

* Corresponding author.

E-mail address: pablocastagnino@posgrad.fcav.unesp.br (P.S. Castagnino).
} 
finishing diets increment the accumulation of VFA and potentially lactate that can alter metabolic activity of rumen microbiota, leading the increment of lactate accumulation and metabolic disorders (Nagaraja and Titgemeyer, 2007; Fernando et al., 2010; Zebeli et al., 2015). Several strategies have been used to manipulate the rumen microbial environment to increase beef cattle performance and to reduce acidosis risks: feeding management (Bevans et al., 2005); use of buffers (Crawford et al., 2008) and antibiotics such as virginiamycin (VM) or ionopheres (Coe et al., 1999); administration of direct fed microbes such as Megasphera elsdenii or Sacchararomyces cerevisiae (Meissner et al., 2010).

The antibiotics, such as VM, have been used at subtherapeutic levels in the feeding of several species of animals as a growth promoter. The VM inhibits the growth of gram-positive lactate-producing bacteria by impairing protein synthesis (Cocito, 1979). Rogers et al. (1995) have shown an increase in the average daily gain (4.6\%) and gain to feed ratio (3.6\%) of steers and heifers receiving VM at $25 \mathrm{mg} / \mathrm{kg} \mathrm{DM}$ in a series of dose-response trials (19 mg-27 mg VM/kg DM). However, in recent years there has been a growing concern about hazards of antibiotic utilization in animal feed. On January 2006, the EU banned the use of antibiotics, including virginiamycin in animal feed. In 2017, the U.S Food and Drug Administration (FDA) published Veterinary Feed Directive (VFD) regulations for medicated feeds, which restrict the use of antimicrobial drugs in feeds without veterinary prescription.

Thus, another strategy to prevent or attenuate excessive lactate production could be increasing the availability of substrate, such as crude glycerol, to lactate-utilizing bacteria (e.g, Megasphaera elsdenii). Glycerol promotes the growth of Megasphaera elsdenii and Selenomonas ruminantium in the rumen environment (Stewart et al., 1997). Glycerol and starch from corn grains present similar attributes as glucose suppliers by increasing the proportions of propionate and butyrate at the expense of acetate (Remond et al., 1993; Wang et al., 2009; Bajramaj et al., 2017). The small intestine digestion of starch in grain corn (30-55\%) may release glucose to be partially absorbed into the bloodstream (Remond et al., 2004). Glycerol can be absorbed at half percentage in the rumen wall and enhance glucose circulation via gluconeogenesis in the liver (Remond et al., 1993). Crude glycerin can replace cereal grains with levels up to $100 \mathrm{~g} / \mathrm{kg}$ DM of feedlot diets of beef cattle without detrimental effects on performance (Parsons et al., 2009; Mach et al., 2009; Lage et al., 2014) and it potentially enhance unsaturated fatty acid deposition on meat (Carvalho et al., 2014; Eiras et al., 2014; Favaro et al., 2016)

We hypothesizes that CG (substrate promoter of lactate-utilizer bacteria) could replace VM (inhibitor of gram-positive lactateproducing bacteria) without impairing rumen fermentation or that combining VM and CG would increment the positive effects on fermentation and promote the growth of bacteria that metabolize lactate. The objective of this study was to evaluate the effect of combining VM (0 or $25 \mathrm{mg} / \mathrm{kg} \mathrm{DM})$ and CG (0 or $100 \mathrm{~g} / \mathrm{kg} \mathrm{DM})$ on fermentation and microbial population of feedlot Nellore cattle. To solve this issue we evaluated the intake and digestibility of dry matter and nutrients, $\mathrm{pH}$, ammonia content, volatile fatty acids, efficiency of microbial protein synthesis and evaluation of the ruminal microbiota.

\section{Material and methods}

\subsection{Animals and feed management}

This study was conducted in accordance with the Brazilian College of Animal Experimentation (COBEA - Colégio Brasileiro de Experimentação Animal) and it was approved by the Ethics, Bioethics, and Animal Welfare Committee (CEBEA; protocol number 021119/11).

Eight rumen cannulated bulls (BW $=600 \pm 34 \mathrm{~kg} 26 \pm 3$ months) were used in a replicated $4 \times 4$ Latin square design with $2 \times 2$ factorial arrangement of treatments: diets without virginiamycin $(\mathrm{VM}-$ ) or virginiamycin at $25 \mathrm{mg} / \mathrm{kg} \mathrm{DM}(\mathrm{VM}+)$ combined with diets without crude glycerin (CG -) or crude glycerin ( $80 \%$ glycerol) $100 \mathrm{~g} / \mathrm{kg}$ DM (CG +). Crude glycerin was acquired from a soybean oil based biodiesel production company ADM, Rondonópolis, Brazil ( $80.3 \%$ of glycerol; $1.59 \%$ of ether extract; $5.03 \%$ of ash and $12.0 \%$ of water). Animals were submitted to 21 days of adaptation to experimental installations and diets. The experiment was conducted for four periods and each lasted for 21 days. Each period contained 14 days for diet adaptation and 7 days of data and sample collection. Animals were housed in individual stalls and fed twice daily at 07:00 and 16:00 h for 10\% refusals. The ration comprising sugarcane bagasse and concentrates in a 20:80 ratio on a DM basis (Table 1) were weighed individually and manually mixed in the troughs of each animal.

\subsection{Sampling and chemical analysis}

Samples of diets (forage and concentrate) and orts from each animal were collected in 5-d sampling period (from days 15 to 19), then composited every period to determine dry matter intake (DMI). Dry matter and nutrients intake were calculated as the difference between amounts offered and refused based on chemical analysis of the composited sample within animals on each period. From days 15 to 19 , feces were collected immediately after each spontaneous defecation, stored in 20-L plastic bags, and at the end of each 24-h collection period the bags were changed and the feces were weighed, manually blended, and aliquots of $10 \%$ of the daily feces excretion were collected. Each fecal sample obtained per day, animal, and period was pre dried in a forced-air oven at $60{ }^{\circ} \mathrm{C}$ for 72 to $96 \mathrm{~h}$. Then, the pre-dried samples from each day were used to compose the final sample. Apparent total tract digestibility of nutrients was calculated as follows: [Nutrient intake $(\mathrm{kg} / \mathrm{d})$-fecal residue $(\mathrm{kg} / \mathrm{d})$ ]/nutrient intake $(\mathrm{kg} / \mathrm{d}) \times 1000$. The composite samples of each material (concentrate, sugarcane bagasse, orts and feces were used to determine DM (method 934.01; Association of Official Analytical Chemists, 1990), ether extract (Association of Official Analytical Chemists, 1990), N was determined by combustion (Leco Instruments Inc., method 976.06) and multiplied by 6.25 to obtain CP, ash (method 924.05; Association of Official Analytical Chemists, 1990) and neutral detergent fiber (NDF) analyses were performed without sodium sulfite and with alpha amylase, and the 
Table 1

Chemical composition of the treatments.

\begin{tabular}{|c|c|c|c|c|}
\hline \multirow{3}{*}{ Proportion of ingredients, $\mathrm{g} / \mathrm{kg} \mathrm{DM}$} & \multicolumn{4}{|c|}{ Treatments $^{\mathrm{a}}$} \\
\hline & \multicolumn{2}{|l|}{ CG- } & \multicolumn{2}{|l|}{ CG +} \\
\hline & VM- & $\mathrm{VM}+$ & VM- & $\mathrm{VM}+$ \\
\hline Sugarcane bagasse & 200 & 200 & 200 & 200 \\
\hline Ground corn & 625 & 625 & 528 & 528 \\
\hline Soybean meal & 136 & 136 & 131 & 131 \\
\hline Crude glycerin & 0.00 & 0.00 & 100 & 100 \\
\hline Urea & 9.00 & 9.00 & 11.0 & 11.0 \\
\hline Mineral premix ${ }^{b}$ & 30.0 & 30.0 & 30.0 & 30.0 \\
\hline Virginiamycin (mg/kg of DM) & 0.00 & 25.0 & 0.00 & 25.0 \\
\hline \multicolumn{5}{|l|}{ Nutrients } \\
\hline DM, g/kg & 852 & 852 & 828 & 828 \\
\hline Crude protein, g/kg DM & 157 & 157 & 156 & 156 \\
\hline aNDFom $^{c}, \mathrm{~g} / \mathrm{kg} \mathrm{DM}$ & 308 & 308 & 296 & 296 \\
\hline EE, g/kg DM & 25.0 & 25.0 & 24.0 & 24.0 \\
\hline Ash, g/kg DM & 74.0 & 74.0 & 76.0 & 76.0 \\
\hline Starch, g/kg DM & 372 & 372 & 322 & 322 \\
\hline $\mathrm{NFC}^{\mathrm{d}}, \mathrm{g} / \mathrm{kg} \mathrm{DM}$ & 436 & 436 & 447 & 447 \\
\hline
\end{tabular}

${ }^{\text {a }}$ Diet without crude glycerin (CG - ) or CG at $100 \mathrm{~g} / \mathrm{kg}$ DM (CG +); diet without VM (VM - ) or VM at $25 \mathrm{mg} / \mathrm{kg} \mathrm{DM}(\mathrm{VM}+$ ).

b Composition (mg/kg of DM) = Calcium: 8000; Phosphoros:3300; sodium: 2700; magnesium: 1400; sulphur: 6300; zinc: 82; cupper: 21; maganase: 52 ; cobalt: 1.3 ; iodine: 1.1 : selenium: 0.35 .

${ }^{\mathrm{c}}$ NDF assayed with a heat stable amylase and expressed exclusive of residual ash.

${ }^{\mathrm{d}}$ Non fiber carbohydrates $=1000-(\mathrm{CP}+\mathrm{EE}+\mathrm{Ash}+\mathrm{NDF})$.

data were corrected for residual ash (Mertens, 2002).

Ruminal samples were taken immediately before feeding and at 3,6,12, $18 \mathrm{~h}$ post feeding on day 20 and day 21 of the sampling week to determine the $\mathrm{pH}$ value (measured after the contents were filtered), and the concentrations of $\mathrm{NH}_{3}-\mathrm{N}$ (mg/dL) and VFA (mM). Two $20-\mathrm{mL}$ aliquots were stored at $-10{ }^{\circ} \mathrm{C}$ and were later used to determine the $\mathrm{NH}_{3}-\mathrm{N}$ concentration as describing by Fenner (1965), adapted for use in Kjeldahl distillation. The VFA concentrations were measured using a gas chromatograph (GC2014, Shimadzu Corporation, Kyoto, Japan) with an HP-INNOWax capillary column $(30 \mathrm{~m} \times 0.32 \mathrm{~mm}$; $0.50 \mu \mathrm{m}$ film thickness; Agilent Technologies, CO, USA) at an initial temperature of $80^{\circ} \mathrm{C}$ which was increased by $20^{\circ} \mathrm{C} / \mathrm{min}$ until a final temperature of $240{ }^{\circ} \mathrm{C}$ was reached.

\subsection{Microbiology}

Ruminal samples used for the quantification of bacteria and protozoa were collected before feeding on day 21 of the sampling week. Ciliate protozoa were identified using a Sedgewick-Rafter chamber as described by Dehority (1984), with the modifications suggested by D’Agosto and Carneiro (1999). Total DNA was extracted using a FastDNA Spin Kit for Soil (MP Biomedicals) according to the manufacturer's instructions.

The relative abundances of archaea (Denman et al., 2007), Megasphaera elsdenii (Ouwerkerk et al., 2002), Streptococcus bovis, Selenomonas ruminantium and Lactobacillus sp. (Khafipour et al., 2009), and three cellulolytic bacterial species, namely, F. succinogenes (Denman and McSweeney, 2006), R. albus (Mosoni et al., 2007), and R. flavefaciens (Denman and McSweeney, 2006), were determined by qPCR using methods of primers standardization of Castagnino et al. (2015).

Data were normalized using the 16S rRNA gene amplified by the total bacterial primer as a 'housekeeping gene'(Denman and McSweeney, 2006) and qPCR was performed using an ABI Prism 7500 and SYBR Green (Applied Biosystems ${ }^{\circledast}$ ) technology.

\subsection{Statistical analysis}

Data of feed intake, digestibility, and ruminal parameters were evaluated in a replicated $4 \times 4$ Latin square design, in a factorial arrangement $2 \times 2$, Crude glycerin (CG) and virginiamycin (VM) using the MIXED procedure of SAS (version 9.2). Statistical model included the fixed effect of VM ( $1^{\circ}$ of freedom, DF), CG (1DF) and the VM $\times$ CG interaction (1DF). Random effects were period (3DF), bulls nested within square (6DF), square (1DF) and residual error.

Data of ammonia, VFA concentrations and $\mathrm{pH}$ were analyzed in a replicated $4 \times 4$ Latin square design with repeated measurements in time (T) using the MIXED procedure of SAS (version 9.2). Statistical model included the fixed effect of VM (1DF), CG (1DF), $\mathrm{T}(4 \mathrm{DF})$ and the interactions: $\mathrm{VM} \times \mathrm{CG}(1 \mathrm{DF}) ; \mathrm{VM} \times \mathrm{T}(4 \mathrm{DF}) ; \mathrm{CG} \times \mathrm{T}(4 \mathrm{DF})$; and $\mathrm{VM} \times \mathrm{CG} \times \mathrm{T}$ (4DF). Random effects were period (3DF), bulls nested within square (6DF), square (1DF) and residual error. First-order autoregressive was the covariate structure used for analysis because it resulted in the lowest Bayesian information criterion. Data were subjected to analysis of variance using the PROC MIXED procedure of SAS (2004). Significance was declared at $P<0.05$, and trends were noted at $0.05<P \leq 0.10$. 


\section{Results}

No interactions were found between CG and VM on intake and total tract digestibility ( $P \geq 0.10$; Table 2). The intake of DM and MO was greater for animal fed with CG + than CG - , independent of VM inclusion $(P<0.05)$. The total tract digestibility, \% DM, OM, CP, starch, NFC remained relatively constant in all diets $(P \geq 0.10)$.

Table 2

Effect of crude glycerin (CG) and virginiamycin (VM) on intake and total tract apparent digestibility of Nellore bulls fed with finishing diets.

\begin{tabular}{|c|c|c|c|c|c|c|c|}
\hline & \multicolumn{7}{|c|}{ Treatments $^{\mathrm{a}}$} \\
\hline & \multicolumn{2}{|l|}{ CG - } & \multicolumn{2}{|l|}{ CG +} & \multirow[b]{2}{*}{$\mathrm{SEM}^{\mathrm{b}}$} & \multicolumn{2}{|c|}{$P$-value ${ }^{c}$} \\
\hline & VM- & $\mathrm{VM}+$ & VM- & $\mathrm{VM}+$ & & CG & VM \\
\hline \multicolumn{8}{|l|}{ Intake, $\mathrm{kg}$} \\
\hline DM & 12.8 & 12.6 & 13.4 & 13.6 & 0.52 & 0.071 & 0.59 \\
\hline $\mathrm{OM}$ & 11.5 & 11.2 & 12.0 & 12.3 & 0.31 & 0.012 & 0.98 \\
\hline $\mathrm{CP}$ & 2.16 & 2.06 & 2.16 & 2.57 & 0.015 & 0.24 & 0.33 \\
\hline NDF & 3.50 & 3.40 & 3.40 & 3.81 & 0.15 & 0.073 & 0.51 \\
\hline Starch & 4.22 & 4.81 & 4.11 & 4.32 & 0.36 & 0.23 & 0.15 \\
\hline NFC & 5.60 & 5.81 & 5.43 & 5.74 & 0.13 & 0.44 & 0.74 \\
\hline \multicolumn{8}{|c|}{ Total tract apparent digestibility, $\mathrm{g} / \mathrm{kg}$} \\
\hline DM & 732 & 733 & 685 & 730 & 37.1 & 0.43 & 0.39 \\
\hline $\mathrm{CP}$ & 817 & 753 & 768 & 820 & 36.9 & 0.81 & 0.79 \\
\hline aNDFom $^{\mathrm{d}}$ & 535 & 533 & 510 & 570 & 36.0 & 0.84 & 0.32 \\
\hline Starch & 919 & 892 & 891 & 883 & 18.2 & 0.22 & 0.12 \\
\hline $\mathrm{NFC}^{\mathrm{e}}$ & 907 & 909 & 871 & 884 & 23.5 & 0.66 & 0.12 \\
\hline
\end{tabular}

${ }^{\text {a }}$ Diet without crude glycerin (CG -) or CG at $100 \mathrm{~g} / \mathrm{kg}$ DM $(\mathrm{CG}+$ ); diet without VM (VM-) or VM at $25 \mathrm{mg} / \mathrm{kg} \mathrm{DM}(\mathrm{VM}+)$.

b Standard error of mean.

c There is no CG $\times$ VM interaction $(P \geq 0.10)$.

d NDF assayed with a heat stable amylase and expressed exclusive of residual ash.

e Non fibrous carbohydrates $=1000-(\mathrm{CP}+\mathrm{EE}+$ Ash + NDF $)$.

There is no interaction $(P \geq 0.10)$ for $\mathrm{CG} \times \mathrm{VM}$, CG $\times$ time, $\mathrm{VM} \times$ time and $\mathrm{VM} \times \mathrm{CG} \times$ time on $\mathrm{pH}, \mathrm{VFA}$ and $\mathrm{NH}_{3}-\mathrm{N}(P \geq 0.01)$. The VFA, mM concentration and $\mathrm{pH}$ was similar among treatments $(P \geq 0.10$; Table 3$)$. The Acetate and A:P ratio decreased in CG + than CG - diets $(P<0.05)$. The propionate, butyrate and valerate proportion was greater in $C G+$ than $C G-\operatorname{diets}(P<0.05)$. The proportion of propionate increased $27.5 \%$ in $\mathrm{CG}+$ diets, regardless of VM inclusion. The $\mathrm{NH}_{3}-\mathrm{N}$ (mg/dL) concentration remained constant among treatments $(P \geq 0.10)$.

Table 3

Effect of crude glycerin (CG) and virginiamycin (VM) on VFA, $\mathrm{pH}$ and $\mathrm{NH}_{3}-\mathrm{N}$ of Nellore bulls fed with finishing diets.

\begin{tabular}{|c|c|c|c|c|c|c|c|c|}
\hline & \multicolumn{5}{|c|}{ Treatments $^{\mathrm{a}}$} & & & \\
\hline & \multicolumn{2}{|l|}{ CG - } & \multicolumn{2}{|l|}{ CG +} & \multirow[b]{2}{*}{$\mathrm{SEM}^{\mathrm{b}}$} & \multicolumn{3}{|c|}{$P$-value ${ }^{\mathrm{c}}$} \\
\hline & VM- & $\mathrm{VM}+$ & VM- & $\mathrm{VM}+$ & & CG & VM & Time \\
\hline $\begin{array}{c}\text { Total VFA, } \\
m \mathrm{M}\end{array}$ & 130 & 117 & 123 & 124 & 15.5 & 0.98 & 0.67 & 0.01 \\
\hline \multicolumn{9}{|c|}{ Individual, mol/100 mol } \\
\hline Acetate & 61.3 & 64.2 & 50.6 & 53.0 & 2.43 & 0.014 & 0.21 & 0.010 \\
\hline Propionate & 20.0 & 17.7 & 25.7 & 26.3 & 2.31 & 0.048 & 0.68 & 0.010 \\
\hline Isobutyrate & 0.95 & 1.11 & 0.99 & 0.98 & 0.18 & 0.56 & 0.35 & 0.011 \\
\hline Butyrate & 12.7 & 12.0 & 16.7 & 14.1 & 1.32 & 0.026 & 0.25 & 0.054 \\
\hline Isovalerate & 3.64 & 3.89 & 3.41 & 3.66 & 0.35 & 0.58 & 0.56 & 0.008 \\
\hline Valerate & 1.47 & 1.23 & 2.55 & 1.98 & 0.16 & 0.007 & 0.012 & 0.061 \\
\hline Ratio A:P & 3.34 & 3.82 & 2.13 & 2.12 & 0.36 & 0.010 & 0.42 & 0.014 \\
\hline $\mathrm{pH}$ & 6.15 & 6.27 & 6.07 & 6.09 & 0.13 & 0.18 & 0.47 & 0.011 \\
\hline $\begin{array}{l}\mathrm{NH}_{3}-\mathrm{N} \\
\quad \mathrm{mg} / \mathrm{dL}\end{array}$ & 28.1 & 27.5 & 23.7 & 26.7 & 4.89 & 0.46 & 0.72 & 0.010 \\
\hline
\end{tabular}

\footnotetext{
${ }^{a}$ Diet without crude glycerin (CG -) or CG at $100 \mathrm{~g} / \mathrm{kg} \mathrm{DM}(\mathrm{CG}+)$; diet without VM (VM-) or VM at $25 \mathrm{mg} / \mathrm{kg} \mathrm{DM}(\mathrm{VM}+)$.

b Standard error of mean.

c There is no interaction $(P \geq 0.10)$ for $C G \times V M, C G \times$ time, $\mathrm{VM} \times$ time, and $C G \times V M \times$ time.
} 
There is no interaction between CG and VM for the microbial population ( $P \geq 0.10$; Table 4$)$. The relative abundance Megasphaera elsdenii doubled in CG + compared with CG - diets $(P<0.05)$. The inclusion of CG decreased Streptococcus bovis $(P<0.02)$. The inclusion of VM or CG did not alter the relative abundance of fibrolityc bacteria $(P \geq 0.10)$.

Table 4

Effect of crude glycerin (CG) and virginiamycin (VM) on relative abundance $\left(\mathrm{n} \times 10^{-3}\right)$ of rumen bacteria of Nellore bulls fed with finishing diets.

\begin{tabular}{|c|c|c|c|c|c|c|c|}
\hline & \multicolumn{7}{|c|}{ Treatments $^{\mathrm{a}}$} \\
\hline & \multicolumn{2}{|l|}{ CG - } & \multicolumn{2}{|l|}{ CG +} & \multirow[b]{2}{*}{$\mathrm{SEM}^{\mathrm{b}}$} & \multicolumn{2}{|c|}{$P$-value ${ }^{\mathrm{c}}$} \\
\hline & VM- & $\mathrm{VM}+$ & VM- & $\mathrm{VM}+$ & & CG & VM \\
\hline Lactobacilus spp. & 4.30 & 4.12 & 0.01 & 0.17 & 0.21 & 0.79 & 0.59 \\
\hline $\begin{array}{l}\text { Streptococcus } \\
\quad \text { bovis }\end{array}$ & 0.58 & 0.56 & 0.42 & 0.16 & 0.19 & 0.021 & 0.22 \\
\hline $\begin{array}{l}\text { Megasphaera } \\
\quad \text { elsdenii }\end{array}$ & 0.14 & 0.05 & 0.17 & 0.20 & 0.10 & 0.033 & 0.73 \\
\hline Selenomonas ruminantium & 30.3 & 51.1 & 17.6 & 14.0 & 2.41 & 0.15 & 0.61 \\
\hline $\begin{array}{l}\text { Ruminococcus } \\
\quad \text { albus }\end{array}$ & 0.58 & 1.86 & 1.52 & 1.42 & 0.53 & 0.62 & 0.17 \\
\hline $\begin{array}{l}\text { Fibrobacter } \\
\quad \text { succinogenes }\end{array}$ & 0.07 & 0.07 & 0.089 & 0.093 & 0.02 & 0.14 & 0.30 \\
\hline
\end{tabular}

${ }^{\text {a }}$ Diet without crude glycerin (CG -) or CG at $100 \mathrm{~g} / \mathrm{kg} \mathrm{DM}(\mathrm{CG}+)$; diet without VM (VM-) or VM at $25 \mathrm{mg} / \mathrm{kg} \mathrm{DM}(\mathrm{VM}+$ ).

b Standard error of mean.

c There is no CG $\times$ VM interaction $(P \geq 0.10)$.

There is no interaction for protozoa counts $(P \geq 0.10$; Table 5). The species of Entodinium, Polyplastron, Isotricha and Eudiplodinium were unaffected by all diets $(P \geq 0.10)$. Total protozoa counts $(P=0.05)$ and Metadinium spp. $(P=0.058)$ had a tendency to decrease in $\mathrm{VM}+$ than $\mathrm{VM}-$ diets.

Table 5

Effect of crude glycerin (CG) and virginiamycin (VM) on rumen protozoa counts of Nellore bulls fed with finishing diets.

\begin{tabular}{|c|c|c|c|c|c|c|c|}
\hline & \multicolumn{7}{|c|}{ Treatments $^{\mathrm{a}}$} \\
\hline & \multicolumn{2}{|l|}{ CG- } & \multicolumn{2}{|l|}{ CG+ } & \multirow[b]{2}{*}{$\mathrm{SEM}^{\mathrm{b}}$} & \multicolumn{2}{|c|}{$P$-value ${ }^{\mathrm{c}}$} \\
\hline & $\mathrm{VM}-$ & $\mathrm{VM}+$ & VM- & $\mathrm{VM}+$ & & CG & VM \\
\hline \multicolumn{8}{|c|}{ Protozoa, $\mathrm{n} \times 10^{4} / \mathrm{mL}$} \\
\hline Entodinium & 4.58 & 4.41 & 4.88 & 3.51 & 1.06 & 0.71 & 0.37 \\
\hline Isotricha & 2.81 & 1.24 & 1.78 & 2.26 & 0.69 & 0.99 & 0.42 \\
\hline Metadinium spp. & 2.39 & 1.18 & 2.37 & 0.66 & 0.73 & 0.74 & 0.058 \\
\hline Polyplastron & 1.64 & 1.24 & 2.43 & 2.05 & 0.92 & 0.11 & 0.22 \\
\hline Eudiplodinium & 1.23 & 1.82 & 2.15 & 1.14 & 0.81 & 0.79 & 0.70 \\
\hline Total protozoa & 12.6 & 10.4 & 14.9 & 9.73 & 2.63 & 0.64 & 0.052 \\
\hline
\end{tabular}

${ }^{\text {a }}$ Diet without crude glycerin (CG - ) or CG at $100 \mathrm{~g} / \mathrm{kg} \mathrm{DM}(\mathrm{CG}+)$; diet without VM (VM -) or VM at $25 \mathrm{mg} / \mathrm{kg} \mathrm{DM}(\mathrm{VM}+)$.

b Standard error of mean.

c There is no $\mathrm{CG} \times \mathrm{VM}$ interaction $(P \geq 0.10)$.

\section{Discussion}

The studies with CG inclusion in feedlot diets at 10\% DM did not show interferences in the DMI (Mach et al., 2009; Lage et al., 2014). In our experiment, the increase in the intake of DM and OM in CG + diets may be occurred due to the physical characteristics of glycerol, such as viscosity, which could to maintain feed particles aggregated (i.e., sugarcane bagasse particles) and to reduce ruminal fill. Furthermore, glycerol can be metabolized within $2 \mathrm{~h}$ in adapted animals (Kijora et al., 1998) by the following routes: fermentation, epithelium absorption or flow to the duodenum (Remond et al., 1993).

In our experiment total VFA content remained relatively constant in all diets. The lack of effect in CG + diets is in accord with experiments with bulls receiving diets containing up to $12 \%$ crude glycerol (Mach et al., 2009) or diets of dairy cows with glycerol replacing corn starch (DeFrain et al., 2004). Coe et al. (1999) did not show effects of VM on total VFA content of Holstein steers fed during adaptation to a high concentrate diet. The authors attributed the moderating influence of VM on ruminal fermentation by a lower Lactobacillus sp. and $S$. bovis counts compared with control treatments. Other factors, such as, the relationship between rumen concentrations of VFA and flux of these from the rumen needs to be considered when interpreting rumen VFA proportions (Clayton et al., 1999). 
The inclusion of VM normally alters the fermentation by increasing propionate relative to other VFA (Nagaraja et al., 1995; Coe et al., 1999; Ives et al., 2002). However, in our experiment VM + diets only decreased the valerate proportion. On the other hand, the CG + diets increased propionate and butyrate proportion at expense of acetate in the rumen. Glycerol is a substrate that is more reduced than the glucose and to maintain the oxidation-reduction balance, the metabolism is directed to formation of more reduced end products, such as propionate (Castagnino et al., 2015). The increase in molar proportion of propionate and acetate: propionate ratio reduction in CG + diets are in agreement with the finds of others (Defrain et al., 2004; Trabue et al., 2007; Krueger et al., 2010; Lage et al., 2017).

Glycerol can be metabolized by Megasphaera elsdenii and Selenomonas ruminantium (Stewart et al., 1997). The higher concentration of butyrate in CG + diets possibly occurred due to an increase in the Megasphaera elsdenii abundance as an active lactate utilizer. The oxidation of lactate to pyruvate generates two hydrogen atoms, and formation of butyrate from acetate may act as an electron sink providing some protection against acidosis due to $\mathrm{H}_{2}$ use (Coe et al., 1999). In our experiment, another factor that facilitated the increase in the Megasphaera elsdenii abundance in CG + diets was the $\mathrm{pH}$ value higher than 6.0. According to Mackie and Gilchrist (1979) a higher ruminal pH would allow a more active population of lactate-utilizing bacteria to ferment lactate to VFA.

The $\mathrm{pH}$ values seem to be in accordance with nutrients digestibilities and total VFA content. The average value of $\mathrm{pH}$ (6.15) for all diets in our experiment may occurred due to the adaption of the animals to concentrate over a number of weeks with the proportion of forage in the diet decreasing over that period. According to Klieve et al. (2003) adaptation process would allow time for the resident populations of lactic acid-utilizing and other starch-fermenting bacteria to keep up with the growth of $S$. bovis and prevent acidosis. Although VM inclusion has been attributed functions of stabilize the ruminal pH (Godfrey et al., 1995), the lack of effect on $\mathrm{pH}$ values in our experiment can be attributed to a fast rate of lactate metabolism in the rumen and the lower retention time with increase in the absorption of VFA.

Diets with CG and VM did not affect fibrolytic bacteria abundance, which can explain the constant value of NDF digestible among diets. Hales et al. (2013) reported no effect of glycerin at $10 \%$ of diet DM on steers DM digestibility. Others have reported a decrease in NDF digestibility at $5 \%$ of pure glycerol in DM of dairy cows diets (Donkin et al., 2009). In vitro trial with pure culture of cellulolytic microbes and glycerol addition at 0.1, 0.5, 1, 2 and 5\%, inhibited the growth of Ruminococcus flavefasciens and Fibrobacter succinogenes and impaired growth and cellulolytic activity of fungus Neocallimastix frontalis when included at 5\% using cellobiose as the sole energy source (Roger et al., 1992).

The $\mathrm{N}$ metabolism seems not be affected by $\mathrm{VM}+$ diets as the $\mathrm{NH}_{3}-\mathrm{N}$ concentration and apparent digestibility of crude protein remained constant compared with VM - diets. According to in vitro studies of Van Nevel et al. (1984) VM decreased deamination and casein degradation. Ives et al. (2002) evaluating finishing diets for steers fed with or without corn gluten feed combined with VM or monensin plus tylosin showed a higher content of $\alpha$-amino nitrogen in the rumen for VM diets, which could potentiate an increase in metabolizable protein supply to cattle. However an additional in vitro trial testing the same diets did not corroborate the hypothesis of a protein-sparing effect. Therefore, more research is needed to clarify the effect of VM on ruminal proteolytic bacteria and intestinal digestion of protein.

Although Megasphaera elsdenii has potential to degrade amino acids in the rumen and to produce branched chain volatile fatty acids (Stewart et al., 1997), its greater abundance in CG + than CG - diets did not increase the release of $\mathrm{NH}_{3}-\mathrm{N}$ in the rumen. Megasphaera elsdenii is deficient in peptidase activity (Rychlik et al., 2002) which can help explain the lack of differences on $\mathrm{NH}_{3}-\mathrm{N}$ content and branch chain volatile fatty acid proportions in diets with crude glycerin. Defrain et al. (2004) reported no effect on ammonia concentration when crude glycerol replaced corn starch in diets of dairy cows.

Ruminal selenomonads are classified into 2 subspecies, ruminantium and lactilytica, strains that utilize lactate and glycerol are placed in the subspecies lactilytica, and all other strains are grouped under the subspecies ruminantium (Ricke et al., 1996). Selenomonas ruminantium was not different across the all treatments in our experiment, which can be explained by substrate specificity as demonstrated by previous authors or inefficacy of VM to inhibit Gram-negative bacteria.

Protozoa contributes to microbial $\mathrm{N}$ reaching the duodenum and it releases in the rumen significant amounts of $\mathrm{H}_{2}$ that is used by methanogens for methane production. In our experiment total protozoa counts decreased in diets with VM. Protozoa counts have generally decreased (Murray et al., 1992; Nagaraja et al., 1995) or not been affected by VM addition (Coe et al., 1999; Ives et al., 2002) in previous studies. The decrease of protozoa counts should allow a reduction of $\mathrm{NH}_{3}-\mathrm{N}$ concentration due to a decrease of protozoal proteolytic and deaminative enzymes (Hristov and Jouany, 2005). Notwithstanding, in our experiment the reduction of protozoa counts did not compensate for a decrease in $\mathrm{NH}_{3}-\mathrm{N}$ concentration.

\section{Conclusions}

Crude glycerin had positive effects on rumen fermentation products and can replace virginiamycin with increment of Megasphaera elsdenii abundance. However, combining virginiamycin and glycerin does not affect positively rumen fermentation and the growth of bacteria that metabolize lactate.

\section{Conflict of interest}

The authors declare no conflict of interest. 


\section{Acknowledgments}

The authors would like to thank Dr. Jeffrey Firkins for comments and suggestions in some topics of this work and the São Paulo Research Foundation (FAPESP- Fundação de Amparo à Pesquisa do Estado de São Paulo) process number 2015/03918-4 and Bellman Nutrição Animal for their financial support.

\section{References}

Association of Official Analytical Chemists, 1990. Official Methods of Analysis, 15th ed. AOAC, Arlington, VA.

Bajramaj, D.L., Curtis, R.V., Kim, J.J.M., Corredig, M., Doelman, J., Wright, T.C., Osborne, V.R., Cant, J.P., 2017. Addition of glycerol to lactating cow diets stimulates dry matter intake and milk protein yield to a greater extent than addition of corn grain. J. Dairy Sci. 100, 6139-6150.

Bevans, D.W., Beauchemin, K.A., Schwartzkopf-Genswein, K.S., McKinnon, J.J., McAllister, T.A., 2005. Effect of rapid or gradual grain adaptation on subacute acidosis and feed intake by feedlot cattle. J. Anim. Sci. 83, 1116-1132.

Castagnino, P.S., Messana, J.D., Fiorentini, G., de Jesus, R.B., San Vito, E., Carvalho, I.P.C., Berchielli, T.T., 2015. Glycerol combined with oils did not limit biohydrogenation of unsaturated fatty acid but reduced methane production in vitro. Anim. Feed Sci. Technol. 201, 14-24.

Carvalho, J.R.R., Chizzotti, M.L., Ramos, E.M., Machado Neto, O.R., Lanna, D.P.D., Lopes, L.S., Teixeira, P.D., Ladeira, M.M., 2014. Qualitative characteristics of meat from young bulls fed different levels of crude glycerin. Meat Sci. 96, 977-983.

Clayton, E.H., Lean, I.J., Rowe, J.B., Cox, J.W., 1999. Effects of feeding virginiamycin and sodium bicarbonate to grazing lactating dairy cows. J. Dairy Sci. 82, $1545-1554$.

Cocito, C., 1979. Antibiotics of the virginiamycin family, inhibitors which contain synergistic components. Microbiol. Rev. 43, $145-192$.

Coe, M.L., Nagaraja, T.G., Sun, Y.D., Wallace, N., Towne, E.G., Kemp, K.E., Hutcheson, J.P., 1999. Effect of virginiamycin on ruminal fermentation in cattle during adaptation to a high concentrate diet and during an induced acidosis. J. Anim. Sci. 77, 2259-2268.

Crawford, G.I., Keeler, C.D., Wagner, J.J., Krehbiel, C.R., Erickson, G.E., Crombie, M.B., Nunnery, G.A., 2008. Effects of calcium magnesium carbonate and roughage level on feedlot performance, ruminal metabolism, and site and extent of digestion in steers fed high-grain diets. J. Anim. Sci. 86, 2998-3013.

D’Agosto, M., Carneiro, M.E., 1999. Evaluation of lugol solution used for counting rumen ciliates. Rev. Bras. Zool. 16, 725-729.

DeFrain, J.M., Hippen, A.R., Kalscheur, K.F., Jardon, P.W., 2004. Feeding glycerol to transition dairy cows: effects on blood metabolites and lactation performance. J. Dairy Sci. 87, 4195-4206.

Dehority, B.A., 1984. Evaluation of subsampling and fixation procedures used for counting rumen protozoa. Appl. Environ. Microbiol. 48, $182-185$.

Denman, S.E., McSweeney, C.S., 2006. Development of a real-time PCR assay for monitoring anaerobic fungal and cellulolytic bacterial populations within the rumen. FEMS Microbiol. Ecol. 58, 572-582.

Denman, S.E., Tomkins, N.W., McSweeney, C.S., 2007. Quantitation and diversity analysis of ruminal methanogenic populations in response to the antimethanogenic compound bromochloromethane. FEMS Microbiol. Ecol. 62, 313-322.

Donkin, S.S., Koser, S.L., White, H.M., Doane, P.H., Cecava, M.J., 2009. Feeding value of glycerol as a replacement for corn grain in rations fed to lactating dairy cows. J. Dairy Sci. 92, 5111-5119.

Eiras, C.E., Marques, Jd.A., Prado, R.Md., Valero, M.V., Bonafé, E.G., Zawadzki, F., Perotto, D., Prado, I.Nd., 2014. Glycerine levels in the diets of crossbred bulls finished in feedlot: carcass characteristics and meat quality. Meat Sci.: Part A 96, 930-936.

Favaro, V.R., Ezequiel, J.M., Almeida, M.T., D’Aurea, A.P., Paschoaloto, J.R., van Cleef, E.H., Carvalho, V.B., Junqueira, N.B., 2016. Carcass traits and meat quality of Nellore cattle fed different non-fiber carbohydrates sources associated with crude glycerin. Animal 10, $1402-1408$.

Fernando, S.C., Purvis 2nd, H.T., Najar, F.Z., Sukharnikov, L.O., Krehbiel, C.R., Nagaraja, T.G., Roe, B.A., Desilva, U., 2010. Rumen microbial population dynamics during adaptation to a high-grain diet. Appl. Environ. Microbiol. 76, 7482-7490.

Godfrey, S.I., Rowe, J.B., Thorniley, G.R., Boyce, M.D., Speijers, E.J., 1995. Virginiamycin to protect sheep fed wheat, barley or oats from grain poisoning under simulated drought feeding conditions. Aust. J. Agric. Res. 46, 393.

Hales, K.E., Kraich, K.J., Bondurant, R.G., Meyer, B.E., Luebbe, M.K., Brown, M.S., Cole, N.A., MacDonald, J.C., 2013. Effects of glycerin on receiving performance and health status of beef steers and nutrient digestibility and rumen fermentation characteristics of growing steers. J. Anim. Sci. 91, $4277-4289$.

Hristov, A.N., Jouany, J.-P., 2005. Factors affecting the efficiency of nitrogen utilization in the rumen. In: Pfeffer, E., Hristov, A.N. (Eds.), Nitrogen and Phosphorus Nutrition of Cattle: Reducing the Environmental Impact of Cattle Operations. CAB International, Wallingford, UK, pp. 117-166.

Ives, S.E., Titgemeyer, E.C., Nagaraja, T.G., del Barrio, A., Bindel, D.J., Hollis, L.C., 2002. Effects of virginiamycin and monensin plus tylosin on ruminal protein metabolism in steers fed corn-based finishing diets with or without wet corn gluten feed. J. Anim. Sci. 80, 3005-3015.

Khafipour, E., Li, S., Plaizier, J.C., Krause, D.O., 2009. Rumen microbiome composition determined using two nutritional models of subacute ruminal acidosis. Appl. Environ. Microbiol. 75, 7115-7124.

Kijora, C., Bergner, H., Gotz, K.P., Bartelt, J., Szakacs, J., Sommer, A., 1998. Research note: investigation on the metabolism of glycerol in the rumen of bulls. Arch. Tierernahr. 51, 341-348.

Klieve, A.V., Hennessy, D., Ouwerkerk, D., Forster, R.J., Mackie, R.I., Attwood, G.T., 2003. Establishing populations of Megasphaera elsdenii YE 34 and Butyrivibrio fibrisolvens YE 44 in the rumen of cattle fed high grain diets. J. Appl. Microbiol. 95, 621-630.

Krueger, N.A., Anderson, R.C., Tedeschi, L.O., Callaway, T.R., Edrington, T.S., Nisbet, D.J., 2010. Evaluation of feeding glycerol on free-fatty acid production and fermentation kinetics of mixed ruminal microbes in vitro. Bioresour. Technol. 101, 8469-8472.

Lage, J.F., Berchielli, T.T., Vito, E.S., Silva, R.A., Ribeiro, A.F., Reis, R.A., Dallantonia, E.E., Simonetti, L.R., Delevatti, L.M., Machado, M., 2014. Fatty acid profile, carcass and meat quality traits of young Nellore bulls fed crude glycerin replacing energy sources in the concentrate. Meat Sci. $96,1158-1164$.

Lage, J.F., San Vito, E., Reis, R.D.A., Delevatti, L.M., Pierre, N.S., Berchielli, T.T., 2017. Ruminal fermentation of Nellore steers fed crude glycerine replacing starch vs. fibre-based energy ingredient in low or high concentrate diets. Acta Sci. Anim. Sci. 39, 57.

Mach, N., Bach, A., Devant, M., 2009. Effects of crude glycerin supplementation on performance and meat quality of Holstein bulls fed high-concentrate diets. J. Anim. Sci. 87, 632-638.

Mackie, R.I., Gilchrist, F.M.C., 1979. Changes in lactate-producing and lactate-utilizing bacteria in relation to pH in the rumen of sheep during stepwise adaptation to a high-concentrate diet. Appl. Environ. Microbiol. 38, 422-430.

Meissner, H.H., Henning, P.H., Horn, C.H., Leeuw, K.J., Hagg, F.M., Fouche, G., 2010. Ruminal acidosis: a review with detailed reference to the controlling agent Megasphaera elsdenii NCIMB 41125 (review). S. A. J. Anim. Sci. 40.

Mertens, D.R., 2002. Gravimetric determination of amylase-treated neutral detergent fiber in feeds with refluxing in beakers or crucibles: collaborative study. J. AOAC Int. $85,1217-1240$.

Mosoni, P., Chaucheyras-Durand, F., Béra-Maillet, C., Forano, E., 2007. Quantification by real-time PCR of cellulolytic bacteria in the rumen of sheep after supplementation of a forage diet with readily fermentable carbohydrates: effect of a yeast additive. J. Appl. Microbiol. 103, 2676-2685.

Murray, P.J., Rowe, J.B., Aitchison, E.M., Winslow, S.G., 1992. Liveweight gain and wool growth in sheep fed rations containing virginiamycin. Aust. J. Exp. Agric. 32, $1037-1043$.

Nagaraja, T.G., Godfrey, S.I., Winslow, S.W., Rowe, J.B., Kemp, K.E., 1995. Effect of virginiamycin on ruminal fermentation in faunated or ciliate-free sheep overfed with barley grain. Small Rumin. Res. 17, 1-8.

Nagaraja, T.G., Titgemeyer, E.C., 2007. Ruminal acidosis in beef cattle: the current microbiological and nutritional outlook. J. Dairy Sci. 90 (Suppl. 1), E17-38.

Van Nevel, C.J., Demeyer, D.I., Henderickx, H.K., 1984. Effect of virginiamycin on carbohydrate and protein metabolism in the rumen in vitro. Arch. Tierernahr. 34, $149-155$. 
Ouwerkerk, D., Klieve, A.V., Forster, R.J., 2002. Enumeration of Megasphaera elsdenii in rumen contents by real-time Taq nuclease assay. J. Appl. Microbiol. 92, $753-758$.

Parsons, G.L., Shelor, M.K., Drouillard, J.S., 2009. Performance and carcass traits of finishing heifers fed crude glycerin. J. Anim. Sci. 87, 653-657.

Remond, B., Souday, E., Jouany, J.P., 1993. In vitro and in vivo fermentation of glycerol by rumen microbes. Anim. Feed Sci. Technol. 41 , 121.

Remond, D., Cabrera-Estrada, J.I., Champion, M., Chauveau, B., Coudure, R., Poncet, C., 2004. Effect of corn particle size on site and extent of starch digestion in lactating dairy cows. J. Dairy Sci. 87, 1389-1399.

Ricke, S.C., Martin, S.A., Nisbet, D.J., 1996. Ecology, metabolism, and genetics of ruminal selenomonads. Crit. Rev. Microbiol. 22 , 27-56.

Roger, V., Fonty, G., Andre, C., Gouet, P., 1992. Effects of glycerol on the growth, adhesion, and cellulolytic activity of rumen cellulolytic bacteria and anaerobic fungi. Curr. Microbiol. 25, 197-201.

Rogers, J.A., Branine, M.E., Miller, C.R., Wray, M.I., Bartle, S.J., Preston, R.L., Gill, D.R., Pritchard, R.H., Stilborn, R.P., Bechtol, D.T., 1995. Effects of dietary virginiamycin on performance and liver abscess incidence in feedlot cattle. J. Anim. Sci. 73, 9-20.

Rychlik, J.L., LaVera, R., Russell, J.B., 2002. Amino acid deamination by ruminal Megasphaera elsdenii strains. Curr. Microbiol. 45, $340-345$.

Stewart, C.S., Flint, H.J., Bryant, M.P., 1997. The rumen bacteria. In: Hobson, P.N., Stewart, C.S. (Eds.), The Rumen Microbial Ecosystem. Blackie Academic \& Professional, London; New York, pp. 10-72.

Trabue, S., Scoggin, K., Tjandrakusuma, S., Rasmussen, M.A., Reilly, P.J., 2007. Ruminal fermentation of propylene glycol and glycerol. J. Agric. Food Chem. 55, 7043-7051.

Wang, C., Liu, Q., Huo, W.J., Yang, W.Z., Dong, K.H., Huang, Y.X., Guo, G., 2009. Effects of glycerol on rumen fermentation, urinary excretion of purine derivatives and feed digestibility in steers. Livest. Sci. 121, 15-20.

Zebeli, Q., Ghareeb, K., Humer, E., Metzler-Zebeli, B.U., Besenfelder, U., 2015. Nutrition, rumen health and inflammation in the transition period and their role on overall health and fertility in dairy cows. Res. Vet. Sci. 103, 126-136. 